\title{
PENYELENGGARAAN PENDIDIKAN KARAKTER DI RAUDATUL ATHFAL (RA) DARUSSALAM KOTA BOGOR
}

\author{
CHARACTER EDUCATION PROGRAM \\ IMPLEMENTATION AT RAUDATUL ATHFAL (RA) \\ DARUSSALAM, BOGOR CITY
}

\author{
Umul Hidayati \\ Puslitbang Pendidikan Agama dan Keagamaan \\ Jl. MH Thamrin No. 6 Jakarta Pusat \\ Email: hidayatikuncoro@yahoo.com
}

Naskah diterima 5 Mei 2016, direvisi 15 Juli 2016, disetujui 30 Juli 2016

\begin{abstract}
This research is aimed at acknowledging the success level of implementation of Character Education program in Raudhatul Athfal (RA) Darussalam Institution, Bogor Barat District, Bogor City, West Java Province. This research uses qualitative method with phenomenological and socio-historical approaches. This research results in finding that the character education in RA Darussalam can be implemented properly and has reached its maximum output. The indicator of this success is the students' capability to absorb and implement the Islam Religion Education materials, which include faith, morals, observance, al-Qur'an and hadiths, as well as good characters. Whereas the supporting factors are, among others, the use of appropriate learning approach and method, the occurrence of learning method diversification, the development of curriculum combining national curriculum, RA-specific curriculum that is full of Islamic teaching values, and characterbased curriculum, the presence of competent and qualified educators graduated from Bachelor Degree (S1) program majoring in Early Aged Children Education, and the provision of complete learning facilities. The impact of this character education implementation success can be felt in the sociological, psychological and political aspects, both for the RA management and parents of students as can be seen from the emerging feeling of content and satisfied for the achieved education output, the increasing public interest in $R A$, the increasing self-confidence and spirit of the educators in performing their teaching duties, the emerging attention of the government (Ministry of Religious Affairs in the Bogor City) towards this institution.
\end{abstract}

Keywords: education program implementation, character education, Rudhatul Athfal

\begin{abstract}
Abstrak
Penelitian ini bertujuan untuk mengetahui tingkat keberhasilan penyelenggaraan Pendidikan Karakter pada Lembaga Raudhatul Athfal (RA) Darussalam, Kecamatan Bogor Barat, Kota Bogor, Propinsi Jawa Barat. Penelitian ini menggunakan metode kualitatif dengan pendekatan fenomenologi dan sosio historis. Penelitian menghasilkan temuan bahwa pelaksanaan pendidikan karakter di RA Darussalam dapat berjalan dengan baik dan mencapai hasil maksimal. Indikator keberhasilan ini dapat dilihat dari kemampuan peserta didik dalam menyerap dan mengimplementasikan materi Pendidikan Agama Islam (PAI) yang meliputi akidah, akhlak, ibadah, al-Qur'an dan hadis, serta perilaku akhlakul karimah. Adapun faktor penunjangnya antara lain penggunaan pendekatan dan metode pembelajaran yang tepat, adanya diversifikasi metode pembelajaran, pengembangan kurikulum yang memadukan kurikulum nasional dan kurikulum khas RA yang sarat nilai-nilai ajaran Islam, serta kurikulum berbasis karakter, adanya pendidik yang kompeten dan berkualifikasi S1 bidang PAUD, dan penyediaan fasilitas pembelajaran yang lengkap. Dampak keberhasilan penyelenggaraan pendidikan karakter ini dapat dirasakan pada aspek sosiologis, psikologis dan politis, baik bagi pengelola RA maupun orangtua siswa yang terlihat dengan munculnya perasaan senang dan puas atas capaian hasil pendidikan, meningkatnya animo masyarakat terhadap RA, meningkatnya rasa percaya diri dan semangat para pendidik dalam melaksanakan tugas mengajar, dan mulai munculnya perhatian pemerintah (Kementerian Agama Kota Bogor) terhadap lembaga ini.
\end{abstract}

Kata kunci: penyelenggaraan pendidikan, pendidikan karakter, Rudhatul Athfal 


\section{PENDAHULUAN}

Pembentukan karakter bangsa merupakan salah satu tujuan dari pendidikan nasional. Undang-undang Nomor 20 Tahun 2003 menyebutkan bahwa tujuan pendidikan nasional adalah berkembangnya potensi peserta didik agar menjadi manusia yang beriman dan bertakwa kepada Tuhan Yang Maha Esa, berakhlak mulia, sehat, berilmu, cakap, kreatif, mandiri, demokratis serta bertanggung jawab. ${ }^{1}$ Makna kalimat tersebut begitu dalam dan sangat mulia, karena dalam tujuan pendidikan tersebut terkandung prinsip keseimbangan, yakni tidak hanya untuk membentuk anak menjadi cerdas saja, tetapi juga berkarakter/ berakhlak mulia, sehingga lahirlah generasi yang intelek, berdayasaing, namun tetap berakhlak mulia.

Selanjutnya, untuk mencapai tujuan tersebut, maka pendidikan karakter harus dilaksanakan sejak usia dini, karena usia dini merupakan periode perkembangan yang sangat penting dalam kehidupan manusia. Pada masa ini, semua potensi yang dimiliki anak berkembang paling cepat, dan seluruh instrumen besar manusia terbentuk, mencakup kecerdasan dan kecakapan psikis, sehingga anak telah memiliki kemampuan untuk berpikir dan mengerti terhadap segala sesuatu. ${ }^{2}$ Hasil penelitian bidang neurologi mengungkapkan bahwa ukuran otak anak usia 2 tahun telah mencapai $75 \%$ dan usia 5 tahun mencapai $90 \%$ dari ukuran otak

\footnotetext{
${ }^{1}$ Undang-undang Nomor 20 Tahun 2003 Tentang Sistem Pendidikan Nasional bab I pasal 3

${ }^{2}$ Cassimir dalam Imam Musbikin. 2010. Buku Pintar PAUD: Tuntunan Lengkap dan Praktis Para Guru PAUD. Yogyakarta: Laksana, h. 39.
}

ketika dia dewasa. ${ }^{3}$ Hasil penelitian lainnya menyebutkan bahwa $50 \%$ kemampuan belajar seseorang mencapai $80 \%$ sebelum usia 8 tahun, dan mencapai $100 \%$ usia 8 hingga 18 tahun. Oleh karena itu, penguatan pendidikan moral (moral education) atau pendidikan karakter (character education) pada anak sejak usia dini sangat penting, karena pada usia dini khususnya masa lima tahun pertama kehidupan anak merupakan "masa emas" (the golden ages) atau "jendela kesempatan" (window opportunity) dalam meletakkan dasar tumbuh kembang anak. ${ }^{4}$ Kualitas tumbuh kembang anak pada masa ini akan menentukan kualitas kesehatan fisik, mental, emosional, sosial, dan perilaku sepanjang hidupnya.

Karenanya, sangat penting, bahkan merupakan suatu keharusan bagi lembaga pendidikan, terutama pendidikan usia ini untuk memperhatikan dan menerapkan pendidikan karakter secara serius. Bebarapa pendidikan tingkat usia dini yang telah menerapkan hal ini adalah RA Istiqlal Jakarta, TKIT An-Najah Jatinom, Klaten dan TK/ RA lain. Di RA Istiqlal, pendidikan karakter diselenggarakan dengan mengembangkan sistem belajar "Integrasi Pendidikan Nilai-nilai Kehidupan Beragama Islam melalui Pendekatan Beyond Centers and Cyrcle Times (BCCT)", dengan mengembangkan tujuh sentra yaitu sentra persiapan ibadah, main peran, bahan alam, balok, seni, musik dan olah tubuh. ${ }^{5}$

${ }^{3}$ Iva Noorlaila. 2010. Panduan Lengkap Mengajar PAUD: Kreatif Mendidik dan Bermain Bersama Anak. Jogjakarta: Kelompok Penerbit Pinus (KPP), h. 15-16.

${ }^{4}$ Ibid., h. 19.

${ }^{5}$ Diambil dari hasil penelitian tentang "Pendekatan Pembelajaran PAUD (Studi di RA Istiqlal Jakarta), yang dilakukan tahun 2011 dan dari buku "Panduan Kegiatan Belajar Melalui Bermain (Integrasi 
Di TKIT An-Najah, pendidikan karakter diselenggarakan dengan mengembangkan Kurikulum Pendidikan Holistik Berbasis Karakter (KPHBK), yaitu model pendidikan secara menyeluruh (holistik) yang fokusnya untuk membangun karakter anak, dengan membangkan 9 karakter, ${ }^{6}$ yaitu cinta Tuhan dan segenap ciptaannya, jujur, amanah, santun, dermawan, suka menolong, percaya diri, kreatif dan pekerja keras, mandiri, disiplin dan tanggungjawab, baik, rendah hati, toleransi, damai, kepemimpinan dan keadilan.

Meskipun beberapa RA sudah menyelenggarakan pendidikan karakter, namun hingga saat ini pemerintah (Kementerian Agama) belum memiliki kebijakan dan konsep yang jelas tentang pendidikan karakter, sehingga penyelenggaraan pendidikan karakter di RA umumnya belum berjalan dengan baik. Persoalan lainnya adalah: 1) masih banyak kelompok anak usia dini yang belum dapat mengakses pendidikan. Hal ini dapat dilihat dari data bahwa sekitar 27\% APK PAUD belum tercapai, (dari prosentase APK tersebut jumlah RA 25.435 lembaga), ${ }^{8}$ 2) kurangnya pemahaman guru akan hakikat

Pendidikan Nilai-Nilai Kehidupan Beragama)" KB dan RA Istiqlal Jakarta.

6 Penjelasan ini diambil dari hasil penelitian tentang "Strategi Pembelajaran PAI (Studi di TKIT AnNajah Jatinom, Klaten), yang dilakukan tahun 2011 dan dari buku "Profil dan Kurikulum Pendidikan Anak Usia Dini (PAUD) An-Najah Jatinom-Klaten”, Tahun 2011/2012

${ }^{7}$ Data APK Paud tahun 2014 baru mencapai 72,9 \%, Kemendikbud, http://www. kemdikbud.go.id/ kemdikbud/berita/2655. Diunduh tanggal 19 April 2015.

${ }^{8}$ Kementerian Agama. 2013. Buku Statistik Pendidikan Islam Tahun Pelajaran 2012/2013. Jakarta: Ditjen Pendidikan Agama Islam, h. 1. dari tujuan pendidikan nasional yaitu untuk membangun manusia yang berkarakter, sehingga dalam proses pembelajarannya lebih menitikberatkan pada aspek kognitif, akibatnya, pembelajaran di PAUD (termasuk RA) lebih mementingkan kemampuan akademik misalnya berkenaan dengan materi membaca, menulis, dan berhitung (calistung) daripada pengembangan aspek emosi dan sosial anak, padahal memaksakan anak usia dini belajar calistung akan beresiko timbulnya stress jangka pendek dan rusaknya perkembangan jiwa anak dalam jangka panjang, 3) 3) kurangnya wawasan guru tentang model, pendekatan dan metode pendidikan karakter yang tepat, akibatnya, proses pembelajaran menjadi pasif dan tidak memberikan pengalaman kongkrit pada anak, ${ }^{10} 4$ ) kurang sinergisnya antara sekolah dan keluarga dalam pembentukan karakter anak, sehingga pembentukan karakter anak menjadi parsial dan tidak holistik, akibatnya muncul gejala anak bersikap inkonsistensi, misalnya bersikap baik di sekolah tetapi di luar sekolah justru sebaliknya, 5) peran guru masih sangat dominan dan penyampaian informasi bersifat satu arah, 6) pengaturan tempat duduk yang cenderung mengisolasi satu anak dengan lainnya, 7) pertanyaan guru cenderung bersifat konvergen daripada divergen, sehingga melumpuhkan kreatifitas anak (disempowering), 8) lemahnya diversifikasi metode pembelajaran. ${ }^{11}$

${ }^{9}$ Elkind D. 2000. Miseducation: Preschoolers at Risk. New York: Knopf, p. 12.

10 Megawangi. 2011. Pendidikan Karakter pada Anak Usia Dini. Jakarta: Indonesia Heritage Foundation (IHF), h. 61.

${ }^{11}$ Martinis Yamin dkk. 2010. Panduan Pendidikan Anak Usia Dini (PAUD). Jakarta: Gaung Persada, h. 31. 
Untuk mengetahui bagaimana penyelenggaraan pendidikan karakter pada RA, tahun 2015 dilakukan penelitian berjudul "Penyelenggaraan Pendidikan Karakter pada Pendidikan Anak Usia Dini (Studi Kasus pada Raudatul Atfal (RA) Darussalam di Kecamatan Bogor Barat, Kota Bogor, Propinsi Jawa Barat)". Penelitian ini penting dilakukan mengingat secara empiris telah banyak RA yang mulai menyelenggarakan pendidikan karakter, namun pada tataran kebijakan, pemerintah belum memiliki konsep yang jelas dan regulasi sebagai payung hukum dalam penyelenggaraan pendidikan karakter.

Berdasarkan konteks penelitian tersebut, maka penelitian ini difokuskan pada permasalahan bagaimana penyelenggaraan pendidikan karakter di RA Darussalam di Kecamatan Bogor Barat, Kota Bogor, Propinsi Jawa Barat, dilihat dari: 1) kebijakan Kemenag dalam penyelenggaraan pendidikan karakter, 2) landasan penyelenggaraan pendidikan karakter, 3) implementasi pendidikan karakter dilihat dari tujuan/fokus, pendekatan, metode, prosedur pembelajaran, pengembangan kurikulum, penggunaan sarana prasarana, peserta didik, kondisi pendidik dan tenaga kependidikan, 3) faktor pendukung dan penghambat, dan 4) output dan outcome dari pelaksanaan pendidikan karakter.

\section{Studi Kepustakaan}

Sejauh pengetahuan penulis, penelitian tentang penyelenggaraan pendidikan karakter pada PAUD memang sudah banyak dilakukan, baik secara personal maupun kelembagaan, misalnya penelitian berjudul "Model Pendidikan Karakter Pada Satuan Pendidikan Anak Usia Dini Islam
(Studi Implementasi Pengembangan Karakter Sejak Usia Dini pada PAUD UIN Sunan Kalijaga Yogyakarta)" oleh Suyadi, S.Ag, M.A, mahasiswa Fakultas Tarbiyah dan Ilmu Keguruan Universitas Islam Negeri Sunan Kalijaga Yogyakarta. Penelitian ini mengungkapkan bahwa pendidikan karakter sejak dini yang diselenggarakan di lembaga PAUD ini ada keterpaduan antara apa yang diajarkan pendidik dengan pola pengasuhan orang tua di rumah terhadap anak dan lingkungan. Penelitian berjudul "Peranan Pendidikan Karakter pada Anak Usia Dini (Studi pada PAUD Darussalam Aceh Besar)" oleh Teuku M. Husni (mahasiswa UIN Aceh), mengungkapkan bahwa faktorfaktor yang mempegaruhi keberhasilan pendidikan karakter anak usia dini ialah lingkungan keluarga, sekolah, masyarakat, dan upaya guru dalam menanamkan pendidikan karakter dengan memberikan pemahaman terhadap perilaku yang baik dan tidak baik, pembiasaan, dan nasihat. Selanjutnya penelitian Rusmini (2008) yang berjudul "Metode Bermain Sambil Belajar, Integrasi Pendidikan Agama Islam dengan Pusat Kegiatan (Sentra) (Studi Empiris di Taman Kanak-kanak Islam Masjid Istiqlal Jakarta Pusat)", mengungkapkan bahwa metode bermain sambil belajar melalui kegiatan sentra, efektif untuk mengintegrasikan nilai-nilai ajaran Islam dan dapat mengarahkan anak untuk menemukan potensi dan kecerdasannya. Berdasarkan hasil penelitian ini, maka penelitian tentang "Penyelenggaraan Pendidikan Karakter pada Pendidikan Anak Usia Dini (Studi Kasus pada Raudatul Atfal (RA) Darussalam di Kecamatan Bogor Barat, Kota Bogor)" yang dilakukan ini semakin menunjukkan tingkat relevansi dan signifikansinya dari 
perspektif kebermanfaatannya dalam upaya peningkatan kualitas pembelajaran pada PAUD khususnya penyelenggaraan pendidikan karakter pada RA.

\section{Kerangka Konseptual}

\section{Pengertian Pendidikan Karakter}

Menurut Wynne, pengertian karakter ada dua, pertama, menunjukkan seseorang yang berperilaku tidak jujur, kejam, dan rakus, sehingga orang tersebut memanifestasikan perilaku buruk. Kedua, menunjukkan seseorang yang berperilaku jujur, belas kasih, dan suka menolong, sehingga memanifestasikan karakter mulia. ${ }^{12}$ Istilah lain, karakter adalah sifatsifat kejiwaan, akhlak/budi pekerti, yang membedakan seseorang dengan lainnya. ${ }^{13}$ Dari pengertian ini maka karakter merupakan nilai-nilai perilaku manusia yang berhubungan dengan Tuhan, diri sendiri, sesamanya, lingkungan, yang terwujud dalam pikiran, sikap, perasaan, perkataan, perbuatan, berdasar norma agama, hukum, dan budaya.

Sedangkan pendidikan karakter adalah proses transformasi nilai sehingga menimbulkan watak baik (transforming values into virtue). ${ }^{14}$ Pendidikan karakter merupakan pendidikan yang membangun aspek kecerdasan kognitif agar peserta didik memiliki kemampuan berinteraksi

${ }^{12}$ Wynne dalam Hamid Darmadi. 2011. Pengantar Pendidikan Kewarganegaraan. Bandung: Alfabeta, h. 55.

${ }^{13}$ Kementerian Pendidikan Nasional. 2008. Kamus Besar Bahasa Indonesia.

${ }^{14}$ Salls, Holly Shepard. 2007. Character education: An Introduction, University Press of America, p. 87. dengan lingkungan sosialnya..$^{15}$ Menurut Sumarni, pendidikan karakter adalah proses pemberian tuntunan kepada peserta didik untuk menjadi manusia yang berkarakter dalam dimensi hati, pikir, raga, rasa dan karsa ${ }^{16}$ Sedangkan menurut Gaffar, pendidikan karakter adalah proses transformasi nilai-nilai kehidupan untuk ditumbuhkembangkan dalam kepribadian seseorang, sehingga menjadi perilaku seseorang tersebut. ${ }^{17}$ Berdasarkan beberapa pengertian ini, maka yang dimaksud pendidikan karakter adalah proses pengarahan dan bimbimbingan terhadap peserta didik melalui transformasi nilainilai agar berperilaku baik dan menjadi manusia yang memiliki kecerdasan kognitif (pengetahuan), keterampilan (life skill), budi pekerti luhur/akhlakul karimah dan mampu berinteraksi dengan lingkungannya. Karakter yang berkualitas perlu dibentuk sejak usia dini, sebab usia dini merupakan masa kritis bagi perkembangan anak selanjutnya. ${ }^{18}$ Dalam pengembangan karakter anak diperlukan kerjasama antara keluarga dan sekolah, ${ }^{19}$ yang dapat dilakukan

${ }^{15}$ Larry P. Nucci, \& Darcia Navaez. 2008. Handbook of Moral and Character Education, New York: Routledge p. 253.

${ }^{16}$ Mukhlas Sumarni dkk. 2012. Konsep dan Model Pendidikan Karakter. Bandung: PT. Remaja Rosdakarya, h. 45 .

${ }^{17}$ Fahry Gaffar dalam Dharma Kesuma dkk. 2012. Pendidikan Karakter Kajian Teori dan Praktek di Sekolah. Bandung: PT.Remaja Rosdakarya, h. 5.

${ }^{18}$ Ratna Megawangi. 2009. Pendidikan Karakter: Solusi Tepat untuk Membangun Bangsa. Depok: Indonesia Heritage Foundation, Cetakan ke 3, h. 21.

${ }^{19}$ Thomas Lickona. 1992. Educating fo Character (Mendidik untuk Membentuk Karakter): Bagaimana Sekolah Dapat Mengajarkan Sikap Hormat dan Tanggungjawab, Pedoman Lengkap Cara Mengajar NilaiNilai Moral (the Journl of Moral Education). Jakarta: PT. Bumi Aksara, h. 57-59. 
melalui strategi: 1) pengelolaan kelas; 2) menciptakan lingkungan positif di sekolah, dan 3) membangun sinergi antara orangtua, sekolah, dan masyarakat. Paling tidak ada empat nilai-nilai pendidikan karakter yang dapat ditanamkan pada anak usia dini, yaitu: aspek spiritual, kepribadian, sosial, dan lingkungan. Sedangkan prinsip pendidikan karakter yang harus dilaksanakan pendidik PAUD yaitu: mendidik melalui keteladanan, mendidik secara berkelanjutan, menyeluruh dan terintegrasi pada seluruh aspek perkembangan, mendidik dengan kasih sayang, mendidik dengan melibatkan pendidik, orangtua, dan masyarakat. ${ }^{20}$ Terkait dengan penelitian ini, aspek-aspek nilai karakter tersebut yang menjadi fokus kajian.

\section{Pengertian Pendidikan Anak Usia Dini (PAUD)}

PAUD adalah suatu upaya pembinaan yang ditujukan kepada anak sejak lahir hingga usia 6 tahun, yang dilakukan melalui pemberian rangsangan pendidikan untuk membantu pertumbuhan jasmani dan rohani, agar anak memiliki kesiapan memasuki pendidikan lebih lanjut. ${ }^{21}$ PAUD dapat diselenggarakan melalui jalur: 1) pendidikan formal (Taman Kanak-kanak (TK), Raudatul Athfal (RA), atau bentuk lain sederajat), 2) pendidikan non formal (Kelompok Bermain (KB), Taman Penitipan Anak (TPA), atau bentuk lain sederajat), 3) pendidikan informal (pendidikan keluarga

\footnotetext{
${ }^{20}$ Kementerian Pendidikan Nasional. 2012. Petunjuk Teknis Penyelenggaraan Pendidikan Karakter pada Pendidikan Anak Usia Dini, h. 3.

${ }^{21}$ Undang-Undang Nomor 20 Tahun 2003 tentang Sistem Pendidikan Nasional (Sisdiknas), Pasal 1 ayat 14.
}

atau yang diselenggarakan lingkungan). ${ }^{22}$ Jenis-jenis PAUD yang berkembang di Indonesia antara lain Taman Kanak-kanak (Kindergarten), Kelompok Bermain (Play Group), Taman Penitipan Anak (Day Care), dan PAUD sejenis (Similar with Play Group) dengan nama bervariasi. ${ }^{23}$

TK adalah satuan pendidikan anak usia dini jalur pendidikan formal usia 4-6 tahun ${ }^{24}$ yang dibagi ke dalam dua kelompok belajar yaitu Kelompok A untuk anak usia $4-5$ tahun dan Kelompok B untuk anak usia 5 6 tahun. RA adalah satuan pendidikan anak usia dini jalur pendidikan formal usia 4 - 6 tahun yang menyelenggarakan program pendidikan khas agama Islam, di bawah binaan Menteri Agama, ${ }^{25}$ yang dibagi ke dalam dua kelompok sebagaimana pada TK. KB adalah satuan pendidikan anak usia dini jalur pendidikan non formal usia 2-4 tahun. TPA adalah layanan penitipan anak usia lahir - 6 tahun yang orangtuanya sibuk bekerja. SPS adalah layanan pendidikan minimal yang dilakukan 1-2 kali/ minggu. Dari pengertian ini, PAUD yang dimaksud dalam penelitian ini adalah PAUD pada jalur pendidikan formal berbentuk RA bagi anak usia 4 - 6 tahun, yang penyelenggaraan pendidikannya dibagi ke dalam dua kelompok belajar yaitu Kelompok A anak usia 4-5 tahun dan Kelompok B anak usia 5-6 tahun.

\footnotetext{
${ }^{22}$ Ibid., Pasal 28.
}

${ }^{23}$ Ahmad Baidowi, "Paud oh Paud" Media Indonesia, Edisi Senin 27 Juni 2011, h. 26.

${ }^{24}$ Kementerian Pendidikan Nasional, 2011, Petunjuk Teknis Penyelenggaraan Taman Kanak-Kanak, Direktorat Pembinaan Anak Usia Dini, Direktorat Jenderal Pendidikan Anak Usia Dini Non Formal dan Informal, h. 18.

${ }^{25}$ Peraturan Menteri Agama (PMA) Nomor 90 Tahun 2013 Bab I Pasal 1 Ayat 2 dan 3. 
Ruang lingkup penyelenggaraan PAUD meliputi delapan komponen yaitu: peserta didik, pendidik dan tenaga kependidikan, sarana prasarana, pembiayaan, kurikulum, peran serta masyarakat, pembinaan dan pengawasan. Adapun penyelenggaraannya dilaksanakan dengan prinsip berorientasi pada kebutuhan anak; sesuai perkembangan anak, learning by playing, menyediakan lingkungan yang mendukung, merangsang munculnya kreativitas, mengembangkan life skill dan melibatkan peran orangtua. Berdasarkan uraian tersebut, terkait dengan penelitian ini, berbagai aspek tersebut yang menjadi kajian dalam penelitian.

\section{METODOLOGI PENELITIAN}

Penelitian ini dilakukan di RA Darussalam Kecamatan Bogor Barat, Kota Bogor. Penelitian dilaksanakan selama 8 bulan (Maret-Oktober 2015). Metode yang digunakan adalah metode kualitatif, karena analisis data bersifat kualitatif, atau alamiah (natural setting), karena penelitiannya dilakukan pada kondisi alamiah. ${ }^{26}$ Sedangkan pendekatannya adalah fenomenologi yaitu berusaha memahami arti dari berbagai peristiwa dan kaitannya terhadap orangorang dalam situasi tertentu, ${ }^{27}$ dan sosio historisyaitu untuk mendiskripsikanapayang terjadi masa lampau dan berguna untuk masa kini, serta untuk melihat kaitannya secara sosiologis yang mempengaruhi pendirian RA dan penyelenggaraan pendidikan karakter di RA.

${ }^{26}$ Sugiono. 2009. Metode Penelitian Kuantitatif Kualitatif Dan R \& D. Bandung: Alfabeta, h. 8

${ }^{27}$ Lexy J. Moleong. 2002. Metode Penelitian Kualitatif, Bandung: Remaja Rosdakarya, Cet. Ke. 16, h. 9 .
Dalam menjaring data, instrumen utama adalah peneliti, sebagai human instrument berfungsi menetapkan fokus penelitian, memilih narasumber/informan, melakukan pengumpulan data, menilai kualitas data, analisis data, menafsirkan data dan membuat kesimpulan. Sumber data penelitian ini berupa kata-kata dan tindakan orang yang diamati atau diwawancarai sebagai sumber data utama (data primer), dan dokumen sebagai data pendukung (data sekunder). Sumber data dimaksud adalah narasumber (responden) yang dianggap kompeten memberikan informasi yaitu kepala, wakil kepala, guru, TU sebagai key informan, masyarakat pengguna (user), pejabat Kemenag, informan lainnya. Sedangkan pengumpulan data dilakukan melalui wawancara mendalam (in-depth interview) dan studi dokumen. Metode berpikir digunakan adalah metode induktif yaitu menganalisis masalah berangkat dari hal-hal yang khusus dan ditarik fakta yang bersifat umum, atau dari data yang berserakan dan kompleks, kemudian dihimpun, dianalisis, dideskripsikan dan ditarik kesimpulan secara umum, selanjutnya dikembangkan pola hubungan tertentu atau menjadi hipotesis. Jika berdasarkan data yang dikumpulkan secara berulang ternyata hipotesis diterima, maka hipotesis tersebut berkembang menjadi teori. ${ }^{28}$

\section{HASIL DAN PEMBAHASAN}

\section{Sekilas tentang RA Darussalam}

Raudatul Athfal (RA) Darussalam yang beralamat di Jalan Raya Cilendek Nomor 29, Desa Cilendek, Kelurahan Cilendek

\footnotetext{
${ }^{28}$ Ibid., h. 6.
} 
Barat, Kecamatan Bogor Barat, Kota Bogor, Propinsi Jawa Barat berdiri tahun 1996, yang kemudian secara resmi terdaftar di Departemen Agama dengan Surat Keputusan Nomor 09/PP-07/1054/1999. Pencetus ide pendirian RA Darussalam ini bernama Halimah Saad (salah seorang putri pengelola dan pemilik Pondok Pesantren Darussalam K.H. Azhari). Adapun tokoh pendirinya adalah K.H. Azhari dan ketiga anaknya yaitu Drs.H. Ikhsan Azzam, K.H. Sanusi Azhari dan Halimah Saad. Pendirian RA Darussalam dilatarbelakangi oleh rasa keprihatinan Halimah terhadap masyarakat yang tinggal di sekitar lingkungan pondok pesantren yang kurang berminat memasukkan putra putrinya ke Pondok Pesantren Darussalam. Atas dasar keprihatinan tersebut maka didirikanlah RA Darussalam, sebagai upaya menjaga keberlangsungan kegiatan Pondok Pesantren Darussalam pada saat itu, agar tetap dapat berjalan dalam mensyiarkan ajaran agama Islam.

Dalam menjalankan peran dan fungsinya sebagai lembaga Pendidikan Anak Usia Dini (PAUD), RA Darussalam memiliki visi "menjadikan anak yang berkarakter, cerdas dan ceria”. Adapun misinya adalah membangun karakter yang Islami (islamic caracter building), melalui penanaman nilai-nilai ajaran Islam dalam kegiatan pembelajaran; mengembangkan kemandirian melalui motivasi dengan slogan "kamu bisa"; dan melaksanakan kegiatan pembelajaran melalui pendekatan happy learning dan active learning.

Saat ini jumlah pendidik yang mengajar di RA Darussalam sebanyak 11 orang. Dilihat dari latar belakang pendidikannya, kondisi pendidik tersebut telah sesuai
Standar Nasional Pendidikan (SNP), ${ }^{29}$ yakni sekitar $80 \%$ berpendidikan S1 bidang pendidikan dan $20 \%$ SLTA, namun sedang dalam proses penyelesaian S1 nya. Dilihat dari kompetensinya, mereka memiliki kemampuan yang sangat baik untuk melakukan tugas mengajar PAUD, karena penerimaan pendidik dilakukan melalui seleksi ketat bidang administrasi dengan melihat kesesuaian pendidikan dengan kebutuhan sekolah, juga seleksi akademik dengan melakukan tes baca tulis al-Qur'an, hafalan juz 30, ayat-ayat pilihan, hadishadis pilihan, asmaul husna, dan praktek mengajar. ${ }^{30}$ Sedangkan jumlah peserta didiknya sebanyak 106 anak. ${ }^{31}$ Sebagian besar mereka merupakan masyarakat kelurahan Cilendek Barat (lokasi RA Darussalam berdiri) dan sebagian berasal dari luar kelurahan. Sejumlah peserta didik tersebut terbagi dalam 8 kelas dan terdiri dari 2 kelas Play Group (PG), 2 kelas A dan 4 kelas $\mathrm{B}$, dengan jumlah peserta didik masing-masing kelas 21 anak dan diajar oleh dua orang pendidik.

Dilihat dari kondisi sarana prasarana yang dimiliki baik berupa bangunan gedung

\footnotetext{
${ }^{29}$ Menurut Standar Nasional Pendidikan Nomor 19 Tahun 2005 Bab VI Pasal 28 Ayat 1 dan 2 serta pasal 29 ayat 1 , disebutkan bahwa pendidik harus memiliki kualifikasi akademik yaitu tingkat pendidikan minimal yang harus dipenuhi oleh seorang pendidik. Adapun tingkat pendidikan yang harus dipenuhi seorang pendidikan pada Pendidikan Anak Usia Dini (PAUD) adalah minimum diploma empat (D-IV) atau sarjana (S1), dengan latar belakang pendidikan tinggi di bidang pendidikan anak usia dini, kependidikan lain, atau psikologi.

${ }^{30}$ Wawancara dengan kepala RA Linda Sari, S.Pd.I dan beberapa orang guru pada hari Jumat tanggal 23 Oktober 2015 pukul 10.30 - 11.30 wib, di ruang kepala RA.

${ }^{31}$ Data diambil dari Statistik Peserta Didik RA Darussalam tahun ajaran 2014/2015.
} 
maupun sarana pembelajaran lainnya, terlihat cukup memadai dari segi kualitas maupun kuantitas. Luas bangunan gedung sekitar $900 \mathrm{M}^{2}$ berdiri di atas tanah seluas $1.500 \mathrm{M}^{2}$ yang merupakan tanah milik Yayasan Darussalam. Bangunan gedung tersebut terdiri dari ruang belajar, kantor, perpustakaan, ruang UKS, aula, kamar mandi, tempat wudu, dapur dan gudang. Sarana lainnya berupa halaman sekitar $300 \mathrm{M}^{2}$, parkiran $100 \mathrm{M}^{2}$, lapangan $100 \mathrm{M}^{2}$, kebun $100 \mathrm{M}^{2}$, dan lainnya $100 \mathrm{M}^{2}$. Prasarana penunjang pembelajaran seperti meja dan kursi belajar, white board, almari buku, loker, meja kursi pendidik, rak sepatu, peralatan kantor, alat bermain outdoor, Alat Permainan Educatif (APE), juga tersedia lengkap.

Dilihat dari kondisi pembiayaan, RA Darussalam tidak memiliki sumber pembiayaan tetap dari pemerintah. Biaya yang digunakan dalam penyelenggaraan pendidikannya, berasal dariorangtua peserta didik melalui iuran bulanan, uang pangkal maupun sumbangan insidentil. Besarnya biaya pendidikan dalam satu tahun sekitar Rp. 4.500.000,- yang terdiri dari Sumbangan Pembinaan Pendidikan (SPP) sebesar Rp. 1.800.000,- s/d Rp. 2.040.000,-, uang pangkal Rp. 2.200.000,-, biaya kegiatan kurikuler dan ekstrakurikuler, kegiatan wisata educative/ field trip, outbond dan akhirussanah. Disamping itu ada biaya tambahan sekitar Rp. 300.000,-, untuk kegiatan bakti sosial, POMG, seminar dan menjenguk orang sakit/ meninggal. ${ }^{32}$ Sedangkan sumbangan dari pemerintah masih bersifat insidentil dan baru beberapa kali menerima yaitu: Tahun

\footnotetext{
${ }^{32}$ Penjelasan ini diperoleh dari wawancara dengan kepala RA Darussalam Linda Sari, S.Pd.I, hari Jumat tanggal 23 Oktober 2015 pukul 10.30-11.30 wib, di ruang kepala $\mathrm{RA}$.
}

2008 berupa Biaya Operasional Pendidikan (BOP) dari Pemerintah Daerah Rp. 3.000.000,; Tahun 2014 berupa Biaya Operasional Sekolah (BOS) dari Kementerian Agama Rp. 7.500.000,- untuk 30 peserta didik; dan Tahun 2014 dari Dinas pendidikan Rp. 12.000.000,-, yang diterima langsung oleh yayasan.

\section{Kebijakan Kemenag dalam Penyelenggaraan Pendidikan Karakter di RA}

Kementerian Agama baik tingkat pusat maupun daerah belum memiliki kebijakan khusus dalam penyelenggaraan pendidikan karakter di RA. Kebijakan pusat yang ada saat ini untuk penyelenggaraan RA berupa Tunjangan Fungsional Guru (TFG) RA sebesar Rp. 250.000,- perguru perbulan, bagi guru yang sudah memiliki Nomor Unik Pendidik dan Tenaga Kependidikan (NUPTK). Guru yang telah memiliki NUPTK juga berhak mengikuti Ujian Kompetensi Guru (UKG), Pendidikan dan Latihan Profesi Guru (PLPG) dan berhak sertifikasi. Kebijakan pusat lainnya adalah Bantuan Operasional RA (BORA) dengan besaran Rp. 310.000,perpeserta didik per tahun yang dimulai tahun 2014. Untuk dapat memperoleh bantuan ini RA harus memenuhi persyaratan antara lain:1) memiliki peserta didik minimal 15 orang; 2) memiliki ijin operasional; 3) lembaga masih eksis berjalan hingga turunnya bantuan; 4) RA telah terakreditasi dan 5) memiliki NPWP, memiliki rekening RA, dan kepala RA diangkat berdasarkan Surat Keputusan pihak berwenang. Tahun 2014, RA yang memperoleh bantuan sekitar 20\%, dan tahun 2015 seluruh RA yang telah memenuhi persyaratan memperoleh 
bantuan. Penentuan kuotanya dilakukan di Kanwil Kemenag Jawa Barat. ${ }^{33}$

Belum adanya kebijakan tentang pendidikan karakter, karena kebijakan di Kementerian Agama masih bersifat top down, sehingga Kementerian Agama Kota Bogor belum berani berijtihad dalam penggunaan anggaran, khawatir akan menyalahi aturan. Oleh Karena itu saat ini lebih memfokuskan pada pemberdayaan operator untuk mengupdate data RA melalui data Emis. Ini sebagai upaya untuk pemberdayaan RA terutama para guru, mengingat sebagian besar guru RA merupakan pegawai honorer. ${ }^{34}$ Upaya lainnya adalah melakukan pembinaan secara kontinyu yang bersifat non budgeting baik dilakukan sendiri maupun menggandeng Ikatan Guru Raudatul Athfal (IGRA) sebagai Organisasi Mitra (ormit). ${ }^{35}$ Pembinaan yang dilakukan adalah meningkatkan kompetensi pendidik dan kepala RA melalui berbagai kegiatan. Entri poin dalam pembinaan ini adalah agar para guru dan kepala RA terus meningkatkan profesionalitas diri dan lembaganya. Targetnya, seluruh guru tersertifikasi dan seluruh lembaga RA terakreditasi. Mendorong RA untuk terkareditasi ini penting, karena selama ini pemahaman tentang RA masih ambigu. Di satu sisi RA merupakan pendidikan formal

\footnotetext{
${ }^{33}$ Data diuraikan dari hasil wawancara dengan Kepala Seksi Pendidikan Madrasah Kantor Kementerian Agama Kota Bogor Ade Sarmili, hari Senin tanggal 9 November 2015 pukul 10.00 s.d. 12.00 wib.

${ }^{34}$ Berdasarkan Data dari Seksi Pendidikan Madrasah Kementerian Agama Kota Bogor bahwa jumlah pendidik yang mengajar di RA se Kota Bogor sebanyak 553 orang, dan hanya 11 orang yang berstatus PNS. Data diambil dari Kosasih (Staf Seksi Pendidikan Madrasah Kementerian Agama Kota Bogor) hari Senin tanggal 9 November 2015.

${ }^{35}$ Ibid.
}

(konsep Kementerian Agama), tapi di sisi lain RA sebagai pendidikan non formal (konsep Kementerian Pendidikan dan Kebudayaan). Pemahaman yang ambigu ini sehingga menimbulkan persepsi yang juga ambigu. Dampaknya tersendatnya kebijakan pemberdayaan RA, salah satunya mandeknya penuntasan akreditasi RA, padahal salah satu syarat masuknya RA dalam ranah kebijakan adalah terakreditasi.

Disamping itu, setting poin Pemda Kota Bogor dalam pemberdayaan lembaga pra sekolah adalah dengan memberdayakan PAUD, yang didukung oleh dana yang mencukupi. Menghadapi kenyataan ini, Seksi Penma Kemenag Kota Bogor terus melakukan pembinaan terhadap RA agar menjadi lembaga pendidikan pra sekolah yang memiliki daya saing (kontestasi) yang setara atau lebih baik dari PAUD-nya Pemda. Untuk mendorong ke arah tersebut, Seksi Penma melakukan upaya dengan menambah nomenclatur RA dengan garis miring TKIT (RA/TKIT). Penambahan nomenclatur ini spontan memperoleh protes dari Dinas Dikbud, namun protes tersebut kemudian berhenti, karena alasan yang diberikan bahwa penamaan RA itu menggunakan bahasa Arab yang dalam bahasa Indonesia sama dengan Taman Kanak-Kanak (TK). Sedangkan Islam Terpadu (IT), karena pembelajaran di RA memang memadukan nilai-nilai ajaran Islam dengan materi ajar lainnya. Kebijakan ini sebagai salah satu strategi meraih pangsa pasar, dimana akhir-akhir ini muncul keresahan di kalangan orangtua terhadap maraknya dekadensi moral yang sering terjadi. Untuk mengantisipasi hal tersebut banyak orangtua yang mencari lembaga pendidikan yang dapat meng-counter keresahan tersebut 
dan mampu memadukan/mengintegrasikan antara nilai-nilai agama dengan materi ajar lainnya semisal RA.

\section{Landasan Penyelenggaraan Pendidikan Karakter di RA Darussalam}

Landasan yang dimaksud di sini adalah dasar pijakan yang digunakan dalam penyelenggaraan pendidikan karakter di RA Darussalam yang meliputi landasan yuridis, filosofos dan sosiologis. Landasan yuridis dalam penyelenggaraan pendidikan karakter di RA Darussalam berupa: a) al-Qur'ân sebagai dasar utama pendidikan Islam, yang berisi segala hal mengenai petunjuk yang membawa kebahagiaan hidup dunia dan akhirat, b) Hadis sebagai landasan kedua, yang juga mengajarkan nilai-nilai etika/ moral dalam kehidupan manusia, dan c) Undang Undang Dasar Nomor 20 Tahun 2003 Tentang Sistem Pendidikan Nasional Bab I Pasal 3 yang menyatakan bahwa pendidikan nasional berfungsi mengembangkan kemampuan dan membentuk karakter serta peradaban bangsa yang bermartabat dalam rangka mencerdaskan kehidupan bangsa.

Sementara landasan filosoisnya adalah al-Qur'an Surat Yasin ayat 80:

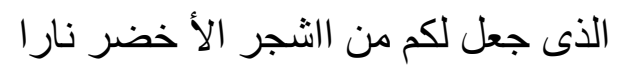

Artinya: "Dialahyang menjadikanuntukmu api dari kayu yang hijau".

Kayu hijau ditafsirkan sebagai pohon, dan sebagai pohon setidaknya memiliki tiga klasifikasi yaitu pohon kayu, pohon buah dan pohon bunga. "Pohon bunga" dipilih sebagai landasan filisofinya, karena bunga melalui proses ekstrak mampu menghasilkan pewangi/pengharum yang semerbak sehingga mampu memberi kesegaran lingkungan sekitarnya. Anak-anak dapat diibaratkan sebagai pohon bunga, melalui ekstrak (pendidikan yang berkarakter) akan dapat membangun karakter yang kuat bagi anak, sehingga menjadi pribadi yang berakhlakul karimah dan selalu menebarkan kebaikan dan menjadi pewangi bagi orangorang di sekitarnya. Sedangkan landasan sosiologisnya adalah memenuhi tuntutan kebutuhan masyarakat terhadap Pendidikan Agama Islam terutama bagi putra putri mereka, sebagai upaya penanaman akidah dan etika/moral sejak dini, yang mampu mendorong anak agar menerapkan akhlakuk karimah, dan menangkal gencarnya arus globalisasi yang mendistorsi nilai-nilai moral bagi masyarakat.

\section{Implementasi Pendidikan Karakter dalam Pembelajaran}

\section{Tujuan / fokus, Pendekatan dan Metode Pembelajaran}

Secara umum, tujuan/fokus pembelajaran di RA Darussalam adalah untuk menanamkan nilai-nilai karakter kepada peserta didik. Adapun karakter yang dikehendaki adalah karakter religius, yakni tertanamnya nilai-nilai ajaran agama Islam sejak dini, agar peserta didik dapat memahami, menghayati dan mengamalkan nilai-nilai ajaran agama Islam tersebut sesuai perkembangan dan usianya yang masih dini. Sedangkan secara khusus adalah untuk menyemai peserta didik agar menjadi manusia yang selalu konsisten dengan fitrahnya (tauhidullâh) yaitu selalu mengesakan Allâh Subhanahu wa Ta'ala, melalui pengenalan nilai-nilai ajaran Islam 
semenjak usia dini. Asumsi dasarnya bahwa dengan mengenalkan nilai-nilai Islam semenjak dini, maka peserta didik akan memiliki akidah yang kuat dan pemahaman tentang ajaran Islam yang lebih baik serta mampu melaksanakan ajaran Islam tersebut dalam kehidupan sehari-hari.

Dalam pembelajaran di RA Darussalam, konsep pendekatan yang digunakan berpusat pada peserta didik (student centred approaches). ${ }^{36}$ Secara teori, ada dua pendekatan dalam pembelajaran yaitu pendekatan yang berpusat pada guru (teacher centred approaches) dan pendekatan bersumber pada siswa (student centred approaches). ${ }^{37}$ Adapun pelaksanaannya, dilakukan melalui dua pendekatan yaitu happy and active learning, yakni ingin menjadikan anak selalu ceria dan aktif dalam belajar. Melalui dua pendekatan ini, ada beberapa metode pembelajaran yang digunakan:1)belajarsambilbermain(learning by playing), 2) belajar sambil bekerja (learning by doing), 3) belajar sambil menari (learning by dancing), 4) belajar sambil bernyanyi (learning by singing), dan 5) pembelajaran terpadu/ terintegrasi (integrated learning). ${ }^{38}$

\footnotetext{
${ }^{36}$ Wawancara dengan para pendirik RA Darussalam sebanyak 4 orang (Suryani, S.Pd.I, Dwi Hana, S.Pd.I, Lia Kurlianah, dan Yanti Suryanti) pada hari Jumat tanggal 23 Oktober 2015 pukul 11.00-12.00 wib di ruang kepala RA Darussalam.

${ }^{37}$ Roy Killen dalam Iif Khoiru Ahmadi dkk. 2011. Strategi Pembelajaran Sekolah Terpadu: Pengaruhnya Terhadap Konsep, Mekanisme dan Proses Pembelajaran Sekolah Swasta dan Negeri. Jakarta : Prestasi Pustaka Publisher, h. 15-16.

${ }^{38}$ Pengamatan yang dilakukan penulis terhadap kelas A1, A2, B1, B2, ply group, kegiatan ekstrakurikuler dan kegiatan imtak, selama tujuh hari yaitu tanggal 19-23 dan 26-27 Oktober 2015, dengan mengamati kegiatan pembelajaran mulai dari kegiatan persiapan sebelum masuk kelas sampai selesai kegiatan pembelajaran.
}

Pemilihan dan penetapan metode pembelajaran $^{39}$ ini didasarkan pada prinsip-prinsip pembelajaran anak usia dini dan dengan alasan yang kuat, sehingga pemilihan dan penetapan metode disesuaikan dan mengarah pada kegiatan pembelajaran aktif dan menyenangkan, sebagaimana pendekatan pembelajaran yang digunakan. Berdasarkan tempat pembelajarannya, digunakan metode klasikal (in class method) yaitu pembelajaran yang dilakukan di dalam kelas atau metode reguler, dan metode keluar kelas (outing class method) yaitu pembelajaran dilakukan di luar kelas dimanapun tempatnya asal sesuai dengan kebutuhan dan materi yang diajarkan. Sedangkan penyampaian materi dilakukan melalui metode ceramah, cerita/ kisah, nasehat, hafalan, pemberian tugas, bercakap-cakap, tanya jawab, demonstrasi dan lain sebagainya.

Berdasarkan teknik pembelajaran ini, digunakan beberapa metode yaitu: 1) metode pindah kelas (moving class method) yaitu pelaksanaan pembelajaran dilakukan dengan berpindah dari kelas tempat belajar semula ke kelas lain khususnya untuk pembelajaran sentra, karena satu kelas hanya digunakan untuk satu sentra; 2) metodebercerita (storymethod) melalui cerita secara lisan dengan teknik yang menarik, sehingga mendorong anak untuk bertanya dan memberikan tanggapan setelah cerita selesai dipaparkan; 3) metode privat (private method) dengan cara mengajar satu persatu

${ }^{39}$ Wawancara dengan para pendidik RA Darussalam sebanyak empat orang (Suryani, S.Pd.I, Dwi Hana, S.Pd.I, Lia Kurlianah, dan Yanti Suryanti) pada hari Jumat tanggal 23 Oktober 2015 pukul 11.00-12.00 wib di ruang kepala RA Darussalam dan memalui . 
terhadap peserta didik khususnya pada materi iqra' dan membaca huruf latin;04 4 ) metode demonstrasi (demonstration method) melalui peragaan alat/media belajar tertentu; 5) metode eksperimen (experiment method) melalui percobaan dan pembuktian terhadap sesuatu yang dipelajari, seperti sentra alam sekitar dan sentra eksplorasi; 6) metode main peran (acting method) yang dilakukan dengan memainkan peran (acting) tokoh tertentu atau biasa disebut sosiodrama; 7) metode bernyanyi (singing method) dengan cara melagukan materi yang dipelajari; 8) metode menari (dancing method) dengan cara menari sambil diiringi musik, untuk materi-materi tentang pemahaman diri sendiri seperti mengenal anggota tubuh dan kegunaannya; 9) metode diskusi/ tanya jawab (discution method) dengan cara memberikan pertanyaan kepada peserta didik untuk memberi rangsangan agar peserta didik aktif untuk berfikir; 10) metode praktek (tathbiq) dengan cara melakukan praktek misalnya praktek shalat, wudu, manasik haji, membagi zakat, dan bahasa asing (Arab dan Inggris); 11) metode menghafal untuk pelajaran tahfiz seperti hafalan surat-surat pendek pada juz 30, ayatayat pilihan, hadis-hadis pendek, doa-doa harian dan Asmaul Husna; 12) metode Audio Visual dengan cara memutar CD melalui layar besar di aula, dengan menayangkan filmfilm yang menceritakan tentang kejujuran, keikhlasan, beramal saleh, kisah-kisah nabi (shiroh nabawiyah), para sahabat, wali dan

\footnotetext{
${ }^{40}$ Pengamatan yang dilakukan penulis terhadap kelas A1, A2, B1, B2, ply group, kegiatan ekstrakurikuler dan kegiatan imtak, selama tujuh hari yaitu tanggal 19-23 dan 26-27 Oktober 2015, dengan mengamati kegiatan pembelajaran mulai dari kegiatan persiapan sebelum masuk kelas sampai selesai kegiatan pembelajaran.
}

alim ulama, juga tentang pendidikan akhlak, dan sebagainya; ${ }^{41}$ 13) metode pembiasaan dengan cara membiasakan melakukan sesuatu kebaikan oleh seluruh warga RA guna membangun karakter (caracter building), agar perilaku yang baik tersebut melebur dan menjadi budaya (culture) di sekolah; 14) metode keteladanan, melalui contoh yang baik dari diri pendidiknya, dan 15) metode penasehatan.

Menurut Nashih Ulwan, metode keteladanan merupakan metode yang berpengaruh besar dan terbukti memiliki keberhasilan dalam mempersiapkan dan membentuk aspek moral, spiritual dan etos sosial peserta didik, mengingat pendidik adalah sosok figur terbaik dalam pandangan peserta didik disamping orangtuanya sendiri. ${ }^{42}$

\section{Prosedur Pembelajaran}

Prosedur pembelajaran adalah tahapantahapan kegiatan yang meliputi kegiatan perencanaan, pelaksanaan, penilaian/ evaluasi dan pencapaian hasil pembelajaran. Dalam fungsi perencanaan, RA Darussalam telah melakukan perencanaan strategik dalam rangka pengembangan kelembagaan dan pembelajaran. Perencanaan pengembangan kelembagaan meliputi; rencana jangka panjang (Rencana Induk Pedoman Sekolah (RIPS)), rencana jangka

${ }^{41}$ Pengamatan terhadap pemutaran film kartun yang diperankan oleh Dodo, Umar dan Zakaria dengan tema beramal saleh, kejujuran dan keikhlasan, selama kurang lebih satu setengah jam, yang diikuti seluruh peserta didik di aula/ruang pertemuan pada hari Jumat tanggal 23 Oktober 2015 sehabis kegiatn imtak pukul 09.30-11.00

${ }^{42}$ Abdullah Nashih Ulwan. 2007. Pendidikan Anak dalam Islam, Jakarta: Pustaka Amani, Jilid II, h. 142. 
menengah (Rencana Pendidikan Tahunan (RPT) atau program tahunan) dan rencana jangka pendek (Rencana Kegiatan Harian (RKH), Rencana Kegiatan Mingguan (RKM) dan Rencana Kegiatan Semesteran (RKS)/ program semesteran).

Dalam perencanaan pengembangan aspek kelembagaan, ${ }^{43}$ rencana jangka panjangnya mencakup pengembangan sumber pembiayaan dengan mencari donatur tetap, pengembangan fasilitas dengan memperbaiki kualitas ruang belajar, menambah ruang audiovisual, mushala dan pengembangan jaringan kerjasama. Rencana jangka menengahnya mencakup peningkatan kualifikasi dan kompetensi pendidik. Sedangkan rencana jangka pendeknya, penambahan prasarana pembelajaran seperti Alat Peraga Edukatif (APE) dan buku-buku cerita.

Sedangkan perencanaan aspek pembelajaran, difokuskan pada pelaksanaan pembelajarannya dan pengembangan materi ajar yang mengarah pada penanaman nilainilai karakter. ${ }^{44}$ Pelaksanaannya tertuang dalam beberapa bentuk desain yaitu Rencana Pelaksanaan Pembelajaran Harian (RPPH) atau Rencana Kegiatan Harian (RKH), Rencana Pelaksanaan Pembelajaran Mingguan (RPPM) atau Rencana Kegiatan Mingguan (RKM), Rencana Pelaksanaan Pembelajaran Semesteran (RPPS) atau Rencana Kegiatan Semesteran (RKS) dan Rencana Pelaksanaan Pembelajaran Tahunan (RPPT) atau Rencana Kegiatan

\footnotetext{
${ }^{43}$ Penjelasan ini diperoleh dari wawancara dengan kepala RA Darussalam Linda Sari, S.Pd.I, hari Jumat tanggal 23 Oktober 2015 pukul 10.30-11.30 wib di ruang kepala RA

${ }^{44}$ Profil Raudatul Athfal (RA) Darussalam tahun 2015, h. 16
}

Tahunan (RKT). Perencanaan kegiatan harian dan mingguan ini merupakan kegiatan pembelajaran intrakurikuler. Sedangkan perencanaan semesteran dan tahunan adalah ekstrakurikuler dan kegiatan lain di luar ekstra dan intrakurikuler.

Pelaksanaan pembelajaran adalah operasionalisasi dari perencanaan pembelajaran, sehingga dalam pelaksanaannya sangat tergantung pada bagaimana perencanaan pembelajaran dibuat. Langkah-langkah pelaksanaan pembelajaran meliputi tiga kegiatan yaitu pembukaan, kegiatan inti dan kegiatan penutup ${ }^{45}$.

Pertama, kegiatan pembukaan, ${ }^{46}$ yaitu kegiatan awal pembelajaran dengan tujuan memfokuskan perhatian dan memotivasi, sehingga peserta didik siap mengikuti pembelajaran. Pada kegiatan pembukaan, RA Darussalam memiliki kegiatan khusus menyambut pagi atau Cahaya Pagi (CP) yang dilakukan di halaman gedung pertemuan sebelum masuk kelas. Kegiatan diawali dengan membaca surah al-fatihah, membaca syahadat, doa menyambut datangnya pagi hari, doa mencari ilmu, menyanyikan lagu-lagu islami dan lagu-lagu lainnya, bahasa Arab tentang anggota tubuh dengan cara dinyanyikan sambil menunjukkan anggota tubuh yang diucapkan dan bahasa Inggris tentang angka dan huruf. Kegiatan

${ }^{45}$ Kementerian Pendidikan Nasional, 2011, Petunjuk Teknis Penyelenggaraan Taman Kanak-kanak, Jakarta: Ditektorat Pembinaan Pendidikan Anak Usia Dini, Direktur Jenderal Pendidikan Anak Usia Dini Non Formal dan Formal, h. 33.

${ }^{46}$ Uraian kegiatan pembukaan dilakukan dengan observasi melihat secara langsung kegiatan pembelajaran di RA Darussalam oleh penulis selama 7 hari yaitu tanggal 19 s.d. 23 dan 26 s.d 27 Oktober 2015 
diakhiri dengan membaca hamdalah. Kegiatan selanjutnya adalah 'tasmi', yaitu mendengarkan dan membaca surat-surat pendek secara bersama-sama. Pada semester I surat yang dibaca sebanyak 10 surat yaitu surat an-Naas, al-Falaq, al-Ikhlash, al-Lahab, an-Nashr, al-Kaafiruun, al-Kautsar, al-Maa'uun, Quraisy dan al-Fiil, dan pada semester II, surat yang dibaca juga sebanyak 10 surat yaitu alMaa'uun, Quraisy, al-Fiil, al-Humazah, al-'Ashr, at-Takaatsuur, al-Qoori'ah, al-'Aadiyaat, azZalzalah dan al-Bayyinah. Tasmi' dilakukan dengan cara menyetel $C D$, seluruh peserta didik dan pendidik mengikutibersama-sama. Dalam kegiatan tasmi' peserta didik dibagi 6 kelompok berdasarkan kelas masing-masing yang dipandu dua orang pendidik, dengan cara duduk melingkar menghadap pendidik (halaqah). Setelah 'tasmi' selesai, seluruh kelompok menuju kelas masing-masing.

Kedua, kegiatan inti, ${ }^{47}$ yaitu kegiatan selama berlangsungnya proses pembelajaran yang dilakukan secara interaktif, inspiratif, partisipatif, menyenangkan dan menantang di dalam kelas. Ada tiga hal yang dilakukan pendidik dalam kegiatan inti yaitu : a) melakukan eksplorasi, yaitu dengan melibatkan peserta didik untuk mencari informasi yang luas dan dalam tentang topik/tema materi yang akan dipelajari, menggunakan beragam pendekatan, metode, media dan sumber belajar, memfasilitasi terjadinya interaki antar peserta didik, antara peserta didik dengan pendidik, dengan lingkungan dan dengan sumber belajar; b) melakukan elaborasi,

\footnotetext{
${ }^{47}$ Uraian kegiatan pembukaan dilakukan dengan observasi melihat secara langsung kegiatan pembelajaran di RA Darussalam oleh penulis selama 7 hari yaitu tanggal 19 s.d. 23 dan 26 s.d 27 Oktober 2015
}

yaitu membiasakan peserta didik membaca, menulis, mewarnai, menjiplak dan lainnya yang beragam melalui tugas-tugas tertentu, memfasilitasi peserta didik untuk diskusi, bertanya, memunculkan gagasan baru baik secara lisan maupun tertulis, memfasilitasi peserta didik dalam belajar kooperatif, kolaboratif, berkompetisi secara sehat, menyajikan hasil kerja individual maupun kelompok; dan c) melakukan konfirmasi, yaitu memberikan umpan balik positif dan penguatan dalam bentuk lisan, tulisan, isyarat, maupun hadiah terhadap keberhasilan peserta didik, memfasilitasi peserta didik melakukan refleksi untuk memperoleh pengalaman belajar yang telah dilakukan, memberi konfirmasi terhadap hasil belajarnya. Materi kegiatan adalah ucapan salam, membaca doa "robbisrohlii sodrii wa yassirlii amrii wakhlul 'uqdatan min lisaanii yafqohuu qoulii”, kegiatan melatih sesnor motoric (tepuk, nyanyi, nari), shalat duha berjamaah, membaca wirid (tasbih, tahmid, takbir dan tahlil) sebanyak 7 kali dan dilanjutkan doa untuk orangtua dan doa kebaikan dunia akhirat, hafalan (doa-doa harian, hadis pilihan, surat-surat pendek, ayat-ayat pilihan, rukun Islam, rukun Iman, lagu-lagu islami), belajar privat iqra satupersatu, time snack (istirahat dan makan makanan ringan yang dibawa oleh masigmasing peserta didik) yang diawali dengan membaca basmalah, doa sebelum makan dan diakhiri baca alhamdulillah.

Ketiga, kegiatan penutup, ${ }^{48}$ yaitu kegiatan akhir dari pembelajaran, yang diisi

\footnotetext{
${ }^{48}$ Uraian kegiatan pembukaan dilakukan dengan observasi melihat secara langsung kegiatan pembelajaran di RA Darussalam oleh penulis selama 7 hari yaitu tanggal 19 s.d. 23 dan 26 s.d 27 Oktober 2015
} 
dengan membuat simpulan, melakukan riview dan memberi umpan balik dengan menanyakan materi yang sudah dipelajari untuk mengetes kemampuan peserta didik dalam menangkap pelajaran hari itu, melakukan tindak lanjut, menyampaikan rencana pembelajaran berikutnya, dan diakhiri dengan doa.

\section{Penerapan dan Pengembangan Materi/ kurikulum Pembelajaran}

Jenis kurikulum yang dikembangkan di RA Darussalam adalah Kurikulum Tingkat Satuan Pendidikan (KTSP) dan kurikulum berbasis karakter. Dilihat dari teknik pembelajarannya, penerapan kurikulum tersebut sudah mengarah kepada Kurikulum 2013, yang dilakukan melalui pembelajaran secara tematik dan integratif. Sedangkan model pembelajaran yang digunakan adalah model Beyond Centers and Circles Time (BCCT) yang terdiri dari sentra persiapan, eksplorasi, rancang bangun, imajinasi, imtak, seni budaya dan alam. ${ }^{49}$ Melalui model BCCT (pembelajaran dilakukan melalui sentra-sentra), peserta didik dapat memperoleh pengalaman bermain yang bervariasi, terlatih sensor motoriknya, berkembang kreatifitasnya, dan nilai-nilai karakter dapat diintegrasikan sesuai sentrasentra. Penyusunan kurikulum mengacu pada ketentuan kurikulum nasional dari Kementerian Pendidikan Kebudayaan dan Kementerian Agama, yang dimodifikasi

${ }^{49}$ Menurut Kepala RA Linda Sari, pembelajaran dengan model sudut dan area ini dilaksanakan beberapa tahun lalu, sekrang pembelajaran dengan menggunakan model sentra. Menurut-Nya model sentra lebih praktis, mudah dan peserta didik lebih mudah menyerap materi yang diajarkan. Wawancara dilakukan hari Jumat tanggal 6 November 2015, pukul 09.00 s.d.10.00 wib di ruang kantor kepala RA. dengan kurikulum khas RA yang sarat nilainilai ajaran Islam dan moral. Formulasi kurikulum tersebut dilakukan dengan mengembangkan beberapa aspek berikut ${ }^{50}$ :

Pertama, pembentukan perilaku melalui pengajaran dan pembiasaan yang meliputi aspek moral, nilai-nilai ajaran Islam, sosial emosional, kemandirian. Adapaun kompetensi yang ingin dicapai adalah peserta didik mampu menghafalkan doa-doa harian, surat-surat pendek, ayat dan hadis pilihan, asmaul husna, melakukan gerakan shalat, mengendalikan emosi, memiliki etika atau moral yang baik,

Kedua, membangun kemampuan berbahasa melalui pengajaran dan pembiasaan. Adapun kompetensi yang ingin dicapai, peserta didik mampu berkomunikasi lisan dengan baik, perbendaharaan kata bertambah, dan mengenal simbol-simbol.

Ketiga, membangun kemampuan kognitif melalui pembelajaran. Kompetensi yang ingin dicapai, peserta didik mampu mengenal konsep konsep bilangan, waktu, ukuran, bentuk geometri, memecahkan masalah dengan bermain puzzle.

Keempat, membangun kemampuan psikomotorik/fisik melalui pembelajaran. Adapun kompetensi yang ingin dicapai, peserta didik mampu melakukan aktivitas fisik seperti kelenturan, keseimbangan, kelincahan dan lainnya.

Kelima, membangun kemampuan seni melalui pembelajaran. Kompetensi yang ingin dicapai, peserta didik mampu mengekspresikan diri melaui karya seni seperti: mewarnai, menggambar,

${ }^{50}$ Profil Raudatul Athfal (RA) Darussalam tahun 2015. 
menciptakan sesuatu, menyanyi, menari, memainkan alat musik, bersajak dan lainnya.

Formulasi kurikulum khas RA Darussalam tersebut meliputi pembelajaran materi akidah, akhlak, ibadah, al-Qur'an dan hadis. Pelajaran akidah, mengajarkan tentang keesaan Allâh Subhaanahu wa Ta'ala. Pokok bahasannya meliputi: 1) Akidah Rubbubiyyah yaitu pengenalan terhadap Allâh Subhaanahu wa Ta'ala, dengan materi mencakup: tema diri sendiri, lingkunganku, kebutuhanku, binatang, tanaman, air, udara, api, serta mengenal Allah melalui hafalan 99 asmaul husna. 2) Akidah Uluhiyyah yaitu penegakan tauhid yang merupakan penjabaran keenam rukun iman, dengan materi meliputi: a) kalimat tauhid beserta maknanya, b) mencintai Allâh dan merasa diawasi oleh-Nya, meminta pertolongan hanya kepada-Nya, dan beriman kepada qadha dan qadar-Nya, c) penanaman aqidah, d) mengajarkan al-Qur'ân dan mencintai al-Qur'ân, dan c) mengajarkan mencintai Rasulullah beserta keluarganya, sahabatnya, para tabi' in dan hamba-hamba yang saleh. ${ }^{51}$

Pelajaran akhlak mengajarkan tentang etika/moral/budi pekerti dan perilaku yang baik dalam kehidupan sehari-hari sesuai dengan yang dicontohkan Rasulullâh Sallallaahu 'Alaihi wa Sallam. Pokok bahasannya meliputi akhlak kepada : 1) Allâh Subhanahu wa Ta'ala, 2) kitab-Kitab Allâh, 3) Rasul Allâh, 4) orangtua/orang yang lebih tua, 5) orang yang lebih muda, 6) teman sebaya, 7) orang yang berilmu, 8) anak yatim, 9) orang cacat, 10) orang miskin, 11) binatang, 12) tumbuh-tumbuhan, 13) etika

${ }^{51}$ Wawancara dengan Yeny dan Yesy (guru kelas B) RA Darussalam pada hari Jumat tanggal 4 November 2015 di ruang kantor R darussalam pukul 10.00 s.d. $11.30 \mathrm{wib}$. berpakaian, 14) etika makan minum dan 15) etika bertamu. Sedangkan penanaman nilainilai akhlak dilakukan dengan memberikan pemahaman tentang etika/moral dan perilaku yang baik melalui pembiasaan dan keteladanan.

Pelajaran ibadah mengajarkan tentang penjabaran kelima rukun Islam dan mempraktekkannya, dengan materi meliputi: 1) syahadat, mencakup pengertian, bacaan dan kandungan isi dua kalimah syahadat, 2) shalat, mencakup pengertian, syarat rukun, tata cara, dan doa sesudah shalat, 3) puasa, mencakup pengertian, jenis-jenis, tata cara, niat dan doa berpuasa, 4) haji, mencakup pengertian, syarat rukun, praktek manasik haji, doa thawaf, sya'i dan wukuf, 5) doa-doa, mencakup 30 doadoa harian, 6) al-Qur'an, mencakup cara membaca al-Qur'an dengan buku iqra 1 s.d. 6; hafalan surat-surat pendek juz 30 dan hafalan ayat-ayat al-Qur'an pilihan, 7) hadishadis pilihan, mencakup 15 hadis.

RA Darussalam juga mengembangkan kurikulum berbasis karakter dengan menerapkan sembilan pilar karakter yaitu: cinta Tuhan (Allâh Subhanahu wa Ta'ala) dan segenap ciptaannya, jujur dan amanah, hormat dan santun, dermawan, suka menolong dan gotong royong, percaya diri, kreatif dan pekerja keras; mandiri, disiplin dan tanggungjawab, baik hati dan rendah hati, toleransi, saling menghargai dan cinta damai, kepemimpinan, keadilan.

\section{Supervisi dan Monitoring}

Supervisi dan monitoring dilakukan satu minggu satu kali oleh kepala RA, dengan mengunjungi satu ruang kelas. Materi yang disupervisi dan dimonitor 
52 meliputi: 1) kesiapan pendidik dalam melakukan pembelajaran dilihat dari RKH yang disusun, apakah mengacu pada RKH tersebut atau tidak, 2) kreativitas pendidik dalam mengemas pembelajaran dan dalam penggunaan media pembelajaran, 3) kemampuan pendidik dalam mengendalikan peserta didik, 4) praktek pembelajaran apakah sesuai kondisi dan situasi peserta didik

\section{Evaluasi/Penilaian}

Evaluasi/penilaian PAUD dapat dilakukan dengan teknik bermacammacam, seperti observasi, penugasan, unjuk kerja, percakapan, hasil karya (porto folio). Evaluasi dilakukan menggunakan instrumen standar dan mengembangkan perangkat penilaian sendiri. ${ }^{53}$ Dari berbagai teknik penilaian tersebut, penilaian yang dilakukan RA Darussalam antara lain penilaian porto folio, observasi, test, penilaian triwulan dan penilaian semester dalam bentuk raport. ${ }^{54}$ Sesuai dengan prinsip pembelajaran PAUD yang tidak mengenal angka dan rangking dalam penilaian, maka penilaian di RA Darussalam juga tidak ada nilai angka dan rangking. Penilaian diberikan melalui pemaparan atau diskripsi tentang perkembangan anak yang dilambangkan dengan huruf BM (Belum Muncul), MM (Mulai Muncul), BSH (Berkembang Sesuai Harapan) dan BSB (Berkembang Sangat Baik).

${ }^{52}$ Wawancara dengan kepala RA Darussalam hari Jumat, tanggal 4 November tahun 2015 pukul 09.0010.00

${ }^{53}$ Sri Karyani, 2011, Penilaian Perkembangan Anak Usia Dini Sesuai Permendiknas No. 58 Tahun 2009, h. 1

54 Wawanrcara dengan guru RA Darussalam Yeny dan Ysy, pada hari Jumat, tanggal 4 November tahun 2015 pukul 10.00-11.30
Sedangkan untuk kegiatan ekstrakurikuler, penilaian dilambangkan dengan huruf $\mathrm{K}, \mathrm{C}$, B dan A.

\section{Pencapian Hasil Pembelajaran dan Penanaman Nilai-nilai Karakter}

Dengan menggunakan tiga metode penilaian yaitu observasi, porto folio dan test, dapat dilihat perkembangan atau capaian hasil belajarar peserta didik selama mengikuti pembelajaran di RA Darussalam dan hasilnya dapat dijadikan bahan evaluasi untuk memperbaiki kekurangan yang ada, selanjutnya dituangkan dalam raport sebagai laporan kepada orangtua peserta didik. Dari pelaksanaan pembelajaran yang telah berlangsung khususnya dalam penananam nilai-nilai karakter, pembelajaran di RA Darussalam telah mencapai hasil yang maksimal. ${ }^{55}$ Indikator keberhasilan ini dapat dilihat dari capaian hasil belajar/ perkembangan peserta didik seperti capaian nilai rata-rata yang mencapai skor Baik dengan nilai (B) atau Berkembang Sesuai Harapan (BSH), pada ketiga aspek yaitu pengetahuan (kognitif), sikap (afektif) dan keterampilan (psikomotor).

Pada aspek kognitif, pencapaian skor B atau BSH ini berarti pelaksanaan pembelajaran di RA Darussalam khususnya dalam penanaman nilai-nilai karakter, mencapai hasil maksimal. Peserta didik mampu menyerap materi pelajaran dengan baik, dan nilai-nilai karakter terserap oleh peserta didik dengan baik. Pada aspek

${ }^{55}$ Wawancara dengan Yeny dan Yesy (guru kelas B) RA Darussalam pada hari Jumat tanggal 4 November 2015 di ruang kantor R darussalam pukul 10.00 s.d. 11.30 wib. 
kognitif, ${ }^{56}$ rata-rata setiap tahunnya sekitar $40 \%$ peserta didik kelompok A dan $65 \%$ kelompok B dapat mencapai skor Sangat Baik (A) atau Berkembang Sangat Baik (BSB), 50 \% kelompok A dan $25 \%$ kelompok B mencapai skor Baik (B) atau Berkembang Sesuai Harapan (BSH), 8 \% kelompok A dan B mencapai skor Cukup (C) atau Mulai Muncul (MM) dan 2\% kelompok A dan B mencapai skor Kurang (K) atau Belum Muncul (BM) perkembangannya.

Tercapainya skor ini berarti dilihat dari kompetensi peserta didik dalam menyerap materi pelajaran khususnya nilainilai karakter di RA Darussalam tercapai maksimal. Indikator pencapaian ini dapat dilihat dari kemampuan peserta didik dalam menyerap dan mengimplementasikan materi PAI yang meliputi akidah, akhlak, ibadah dan al-Qur'an-hadis. Pencapaian pada materi akidah misalnya, peserta didik telah mengerti dan memahami bahwa Allâh Subhanahu wa Ta'ala sebagai Tuhan Maha pencipta dengan segala ciptaannya, telah mampu menghafal kalimah syahadat, rukun iman dan 99 asmaul husna. Pencapaian pada materi akhlak, peserta didik telah mengerti tentang perilaku yang baik/akhlakul karimah. Sedangkan pada materi ibadah, peserta didik telah mampu menghafal rukun Islam, mengerti tentang shalat, mampu menghafal bacaan shalat dan doadoa sesudah shalat. Pencapaian pada materi al-Qur'ân, peserta didik sudah mampu membaca al-Qur'ân sesuai dengan makhraj dan tajwidnya, dapat menyelesaikan iqra 6, mampu menghafal surat-surat pendek juz

${ }^{56}$ Wawancara dengan Guru RA Darussalam Yesy dan Yeny pada hari pada hari Jumat tanggal 4 November 2015 di ruang kantor R darussalam pukul 10.00 s.d. 11.30 WIB.
30 sebanyak 15 surat dan ayat-ayat pilihan seperti ayat Qursi, ayat 284 s.d. 286 surat alBaqarah, dan ayat 23 s.d. 27 surat al-Isra'. Pencapaian pada materi hadis, peserta didik telah mampu menghafal 15 hadis. Sedangkan Pencapaian pada materi doa, peserta didik telah mampu menghafal seluruh doa-doa yang ditentukan sebanyak 30 doa harian.

Pada aspek psikomotor, pencapaian skor B atau BSH ini berarti peserta didik mampu mengimplementasikann nilainilai karakter dengan baik, seperti: 1) mampu mengerjakan ibadah misalnya dapat melakukan shalat dengan baik dan benar bacaan dan gerakan shalatnya, mampu melakukan wudu serta membaca doa sebelum dan sesudah wudu, mampu mengerjakan puasa setengah hari, mampu melakukan gerakan-gerakan manasik haji serta membaca doa thawaf, sya'i, dan wukuf; 2) mampu mengurus keperluannya sendiri seperti cuci tangan, buang air kecil, melipat mukena, memakai pakaian, sepatu, merapikan tas dan sebagainya.

Pada aspek afektif, pencapaian skor B atau BSH ini berarti penanaman nilai-nilai karakter terserap dengan baik oleh peserta didik. Hal ini dapat dilihat dari meleburnya nilai-nilai karakter dalam sikap dan perilaku yang akhlakul karimah yang tercermin dari tutur kata dan perilaku yang santun, misalnya munculnya rasa hormat pada guru, orangtua, orang yang lebih tua, mengasihi saudara dan teman-temannya, tidak suka berkelahi, memiliki sifat dermawan, disiplin waktu, jujur dan amanah, memiliki toleransi tinggi terhadap perbedaan (warna kulit, kemampuan, suku, bahasa, bahkan agama) yang ada pada orang lain. 
Selain melalui pencapaian hasil pembelajaran materi PAI, pencapaian hasil yang maksimal ini juga dapat dilihat dari berkembangnya psikologi peserta didik seperti mampu bergaul, berkembang sensor motoriknya sehingga memiliki keterampilan minimal dan mampu mengerjakan keperluannya sendiri, seperti bisa memakai maju dan sepatu, memakai dan merapikan mukenah, bisa mewarnai, menjiplak, melipat kertas dalam bentuk seni, meronce, menulis huruf dan angka.

Disamping berhasil di bidang akademik, RA Darussalam juga berhasil di bidang non akamik melalui pendidikan ekstrakurikuler, seperti juara 2 lomba sekolah sehat tingkat propinsi, juara 3 dai cilik, juara 2 mewarnai, juara 1 tari kreasi, juara 3 kreativitas mainan edukatif, tingkat Kota Bogor, dan lainnya.

\section{Faktor Pendukung dan Penghambat}

Keberhasilan penyelenggaraan pendidikan karakter di RA Darussalam didukung oleh banyak faktor antara lain: kondisi pendidik dan tenaga kependidikan telah memadai dari segi kualifikasi dan kompetensinya, kondisi sarana prasrana telah mencukupi dari segi jumlah dan variasinya, adanya kurikulum khas RA dan kurikulum berbasis karakter, dan minat masyarakat yang tinggi sebagai modal dasar dalam menjaring input peserta didik. Adapun beberapa faktor yang masih menghambat adalah: belum memiliki tenaga pendidik untuk kegiatan ekstrakurikuler, sarana ruang kelas yang belum ideal dari segi luas dan belum memiliki ruang kelas khusus untuk pembelajaran audiovisual, sarana pembelajaran berbasis TIK masih terbatas, dan sumber pembiayaan masih terbatas.

\section{Dampak Keberhasilan Penyelenggaraan Pendidikan Karakter}

Keberhasilan penyelenggaraan pendidikan karakter yang dilakukan melalui pembelajaran di RA Darussalam telah berpengaruh positif baik bagi user (pemakai) khususnya orangtua peserta didik maupun bagi sekolah. Bagi orangtua, pengaruh positif terlihat dari meningkatknya pemahaman peserta didik terhadap materi PAI dan kemampuan mengimplementasikan dalam perilaku sehari-hari, sehingga orangtua merasakan senang dan puas atas hasil yang dicapaidaripembelajaran diRADarussalam. ${ }^{57}$ Menurut mereka, menyekolahkan anak di RA Darussalam memiliki beberapa keuntungan: 1) anak memiliki pemahaman terhadap materi yang diajarkan dan kemampuan mengimplementasikannya, 2) anak memperoleh materi pelajaran bernuansa karakter yang maksimal dan bervariasi, baik materi PAI seperti pelajaran akidah, akhlak, ibadah, al-Qur'an ${ }^{58}$ maupun

${ }^{57}$ Berdasarkan data dari isian IPD yang dilakukan oleh orangtua peserta didik sebanyak 13 orang (6 orang merupakan orangtua kelas B dan 7 orang merupakan orangtua kelas A), sekitar $77 . \%$ orangtua menyatakan bahwa pendidikan agama Islam yang diajarkan di RA Darussalam sangat memadai, sehingga mampu membekali anak tentang nilainilai ajaran agama Islam, sekitar $62 \%$. Orangtua menyatakan pendidikan agama Islam yang diajarkan di RA Darussalam sangat memadai dan mampu membangun perilaku anak yang akhlakul karimah, $692 \%$. Orangtua menyatakan pendidikan agama Islam yang diajarkan di RA Darussalam sangat memadai dan mampu menanamkan akidah yang kuat. (Kuesioner diisi oleh 13 orangtua peserta didik pada hari Kamis tanggal 22 Oktober 2015) pukul 09.00 s.d. 11.00 wib di ruang play group RA Darussalam.

${ }^{58}$ Berdasarkan data dari isian IPD oleh orangtua peserta didik, sebanyak $69 . \%$ orangtua menyatakan bahwa hasil yang diraih putra putrinya selama belajar di RA Darussalam antara lain anak bisa membaca al-Qur'an dengan lancar, 77 \% menyatakan anak 
materi umum seperti membaca, menulis, berhitung, menggambar, mewarnai, dan menjiplak. Setelah belajar selama 2 tahun melalui kelompok A dan B, kompetensi anak meningkat signifikan dan perilaku anak menjadi lebih baik, ${ }^{59}$ 3) sensor motorik dan kecerdasan anak berkembang baik, 4) anak menjadi disiplin belajar, bermain, makan, shalat, istirahat; 5) anak terpelihara kesehatannya, karena adanya pemeriksaan kesehatan 3 bulan sekali.

Pengaruh positif yang dirasakan sekolah mencakup pengaruh psikologis, sosiologis maupun politis. Pengaruh psikologis ditandai dengan capaian hasil belajar/ perkembangan peserta didik yang maksimal, semakin memupuk rasa percaya diri para pendidik dan memacu semangat untuk lebih giat lagi melakukan inovasi dan krativitas dalam pembelajaran. Pengaruh sosiologisnya, semakin meningkat animo masyarakat terhadap RA Darussalam, yang terlihat tiga tahun terakhir jumlah peserta didik mengalami peningkatan signifikan.

rajin membaca al-Qur'an setiap hari, 77 \%. orangtua menyatakan anak memiliki hafalan surat sebanyak 10-19 surat pendek, $69 \%$. Orangtua menyatakan, anak mampu menghafal doa-doa sebanyak 10-19 doa, $54 \%$ orangtua menyatakan anak mulai bisa mengerjakan dan rajin shalat dan $77 \%$ orangtua menyatakan anak memiiki perilaku yang baik.

${ }^{59}$ Berdasarkan data dari isian IPD oleh orangtua peserta didik, sekitar $62 \%$ orangtua menyatakan bahwa pendidikan karakter yang diajarkan di RA Darussalam sangat memadai dan mampu menanamkan nilai-nilai kejujuran kepada anak; sekitar 77 \% menyatakan mampu menanamkan kedisiplinan; sekitar $62 \%$ menyatakan mampu menanamkan sikap cinta tanah air; sekitar $69 \%$ menyatakan mampu menanamkan cinta kasih sayang terhadap sesamanya; dan sekitar $69 \%$ mengatakan mampu menanamkan sikap suka menolong. Kuesioner diisi oleh 13 orangtua peserta didik pada hari Kamis tanggal 22 Oktober 2015) pukul 09.00 s.d. 11.00 wib di ruang play group RA Darussalam.
Pada tahun 2012/13 jumlah peserta didik 75 orang, maka pada tahun 2013/14 meningkat 14 orang menjadi 89 orang dan pada tahun 2014/15 meningkat 17 orang menjadi 106 orang. ${ }^{60}$ Adapun pengaruh politis, dapat dilihat dari meningkatnya perhatian Kemenag Kota Bogor antara lain dengan mengikutkannya dalam berbagai lomba tingkat kabupaten dan propinsi sebagaimana diuraikan di atas. Membaiknya capaian hasil belajar di RA Darussalam ini membuat RA Darussalam selalu dipercaya dan dipilih untuk mewakili Kota Bogor dalam berbagai ajang lomba tingkat propinsi.

\section{PENUTUP}

Penelitian ini menghasilkan kesimpulan bahwa penyelenggaraan pendidikan karakter yang dilakukan di RA Darussalam berjalan dengan baik dan dapat mencapai hasil maksimal. Indikator keberhasilan ini dapat dilihat dari kemampuan peserta didik dalam menyerap dan mengimplementasikan materi PAI yang meliputi akidah, akhlak, ibadah, al-Qur'an, hadis dan lainnya, dan dilihat dari capaian hasil belajar/ perkembangan peserta didik seperti capaiam nilai rata-rata hasil belajar yang mencapai skor Baik dengan nilai (B) atau Berkembang Sesuai Harapan (BSH) pada tiga aspek yaitu pengetahuan (kognitif), sikap (afektif) dan keterampilan (psikomotor).

Beberapa faktor penunjang suksesnya penyelenggaraan pendidikan karakter di RA Darussalam ini antara lain penggunaan pendekatan dan metode pembelajaran yang tepat dan sesuai dengan kondisi anak usia

${ }^{60}$ Diambil data dari statistik peserta didik RA Darussalam tahun 2014/15 
dini, serta diversifikasi metode pembelajaran yang diterapkan, pengembangan kurikulum yang memadukan antara kurikulum nasional dan kurikulum khas RA yang bernuansa nilai-nilai ajaran Islam serta kurikulum berbasis karakter, kondisi pendidik yang sebagian besar memiliki kualifikasi S1 bidang pendidkan PAUD dan memiliki kompetensi mengimplementasikan pendidikan karakter (menguasai materi dan menguasai strategi pembelajaran anak usia dini yang baik), penyediaan fasilitas penunjang pembelajaran yang lengkap dan memadai, dan tersedianya bahan ajar sebagai acuan pendidik dalam menjalankan tugas mengajar.

Keberhasilan pendidkan karakter ini memberikan dampak positif baik secara sosiologis, psikologis dan politis. Secara sosiologis, keberhasilan penanaman nilai-nilai karakter di RA Darussalam berdampak bagi orangtua yang ditandai dengan munculnya perasaan senang dan puas atas peningkatan pemahaman putra-putri mereka terhadap materi PAI dan kemampuan mereka dalam mengimplementasikan materi tersebut dalam perilaku sehari-hari. Sedangkan dampak positif bagi masyarakat luas adalah semakin meningkatnya animo masyarakat terhadap RA Darussalam, sehingga input peserta didik terus meningkat dari tahun ke tahun. Peningkatan input ini secara psikologis turut meningkatkan rasa percaya diri dan semangat bagi para pendidik dalam melaksanakan tugas pembelajaran. Sedangkan secara politis, meningkatnya kepercayaan masyarakat berpengaruh terhadap perhatian dan kebijakan pemerintah (Kementerian Agama
Kota Bogor), yang mulai menunjukkan perhatiannya terhadap lembaga ini.

Mengingat masih banyaknya kendala yang dihadapi RA Darussalam dalam penyelenggaraan pendidikan karakter, direkomendasikan kepada pihak-pihak terkait: 1) Kepada Direktorat Jenderal Pendidikan Islam melalui Direktorat Pendidikan Madrasah untuk menyusun konsep yang jelas tentang pendidikan karakter pada PAUD khususnya RA, mengeluakan regulasi penyelenggaraan pendidikan karakter pada PAUD, dan mengeluarkan anggaran operasional pendidikan yang memadai untuk RA, baik untuk honor guru, sarana prasarana, pengembangan kurikulum, peningkatan kualitas SDM dan sebagainya; 2) Kepada Kementerian Agama Kota Bogor, untuk melakukan pembinaan yang intensif terhadap seluruh RA terkait penyelenggaraan pendidikan karakter, baik pembinaan SDM, pengembangan kurikulum, strategi pembelajarannya; serta memberikan perhatian khusus bagi RA yang sudah menyelenggarakan pendidikan karakter dengan memasukkan pada setiap program-programnya, 3) Kepada para pendidik dan kepala RA Darussalam untuk: a) meningkatkan kompetensi dan kualifikasi melalui berbagai kegiatan agar meningkat profesionalitasnya dalam menjalankan tugas pembelajaran, b) meningkatkan kualitas penyelenggraan pendidikan karakter dengan mengembangkan diversifikasi metodologi pembelajaran yang bervariasi dan menyenangkan, c) meningkatkan kualitas penyelenggaraan pendidikan karakter dengan mengembangkan sistem full day school, d) meningkatkan kualitas penyelenggaraan pendidikan 
karakter dengan memperkuat bidang tahfiz, e) meningkatkan sarana-prasarana pembelajaran baik dari segi jumlah maupun kualitasnya, sehingga memenuhi kondisi ideal, f) mengadakan jaringan kerjasama dengan berbagai instansi baik lembaga pendidikan maupun non pendidikan untuk meningkatkan kualitas pembelajaran, g) memperluas sumber-sumber pendanaan dengan menggandeng berbagai pihak dari kalangan masyarakat luas, 4) Kepada masyarakat umum khususnya masyarakat sekitar RA, untuk lebih berperan aktif dalam penyelenggaraan pendidikan karakter di RA Darussalam baik melalui dukungan pendanaan, tenaga, pikiran, maupun ide-ide kreatif.

\section{UCAPAN TERIMA KASIH}

Kegiatan penelitian ini dapat berjalan lancar karena adanya keterlibatan dan bantuan berbagai pihak. Oleh karena itu, selaku peneliti mengucapkan terima kasih yang tak terhingga kepada: a) Kepala Puslitbamg Penda dan Keagamaan yang telah memberikan pengarahan dalam penyusunan dan pembahasan DO dan IPD; 2) Para narasumber, teman-teman peneliti, dan lainnya yang telah memberikan kritik, saran, dan masukan dalam pembahasan DO dan IPD; 3) Para pembantu lapangan yang telah memandu peneliti ke lokasi penelitian; 4) Seluruh responden (kepala, guru dan pegawai RA Darussalam), Kasi Penma Kemenag Kota Bogor, tokoh masyarakat, para orangtua peserta didik dan semua pihak yang telah berkenan menjadi responden dan berkontribusi dalam kegiatan penelitian ini.

\section{DAFTAR PUSTAKA}

Baidowi, Ahmad, Paud oh Paud, Media Indonesia: Edisi Senin 27 Juni 2011.

Darmadi, Hamid (2011): Pengantar Pendidikan Kewarganegaraan, Bandung, Alfabeta.

Elkind D. (2000): Miseducation Preschoolers at Risk, New York, Knopf.

Gaffar, Fahry (2012): dalam Kesuma, Dharma, dkk, Pendidikan Karakter Kajian Teori dan Praktek di Sekolah, Bandung, PT. Remaja Rosdakarya.

Hidayati, Umul (2010): hasil penelitian tentang "Metode Pembelajaran PAUD (Studi di RA Istiqlal Jakarta).

Hidayati, Umul (2011): hasil penelitian tentang "Strategi Pembelajaran PAI (Studi di TKIT An-Najah Jatinom, Klaten).

Kementerian Agama (2012): Buku Statistik Pendidikan Islam Tahun Pelajaran 2011/2012, Jakarta: Ditjen Pendidikan Agama Islam.

Kementerian Pendidikan Nasional (2012): Petunjuk Teknis Penyelenggaraan Pendidikan Karakter pada Pendidikan Anak Usia Dini.

Kementerian Pendidikan Nasional (2011): Petunjuk Teknis Penyelenggaraan Taman Kanak-Kanak, (Direktorat Pembinaan Anak Usia Dini, Dirjen PAUD Non Forman dan Informal.

Kementerian Pendidikan Nasional (2008): Kamus Besar Bahasa Indonesia,.

Lickona, Thomas (1992): Educating fo Character (Mendidik untuk Membentuk Karakter): Bagaimana Sekolah Dapat Mengajarkan Sikap Hormat dan Tanggungjawab, Pedoman Lengkap Cara Mengajar NilaiNilai Moral (the Journl of Moral Education), Jakarta, PT. Bumi Aksara. 
Megawangi, Ratna (2011): Pendidikan Karakter pada Anak Usia Dini, Jakarta: Indonesia Heritage Foundation.

Megawangi, Ratna (2004): Pendidikan Karakter (Solusi Tepat untuk Membangun Bangsa), Depok, Indonesia Heritage Foundation.

Moleong, Lexy J. (2002): Metode Penelitian Kualitatif, Bandung: Remaja Rosdakarya, Cet. Ke. 16.

Musbikin, Imam (2010): Buku Pintar PAUD : Tuntunan Lengkap dan Praktis Para Guru PAUD, Yogyakarta, Laksana.

Noorlaila, Iva (2010): Panduan Lengkap Mengajar PAUD : Kreatif Mendidik dan Bermain Bersama Anak, Jogjakarta, Kelompok Penerbit Pinus (KPP).

Nucci, Larry P. \& Darcia Navaez (2008): Handbook of Moral and Character Education, New York, Routledge.

Salls, Holly shepard (2007): Character education (An Introduction), University Press of America.

Sugiono (2009): Metode Penelitian Kuantitatif Kualitatif Dan R \& D, Bandung, Alfabeta.

Sumarni, Mukhlas, dkk (2012): Konsep dan Model Pendidikan Karakter, Bandung, PT.Remaja Rosdakarya.

Tim Media (2010): Kamus Lengkap Bahasa Indonesia, Media Center.

Ulwan, Abdullah Nashih (2007): Pendidikan Anak dalam Islam, Jakarta, Pustaka Amani, Jilid II

Wibowo, Agus (2012): Pendidikan Karakter (Strategi Membangun Karakter Bangsa Berperadaban), Yogyakarta, Pustaka Pelajar.

Yamin, Martinis, dkk. (2010): Panduan Pendidikan Anak Usia Dini (PAUD), Jakarta, Gaung Persada.
Zuchdi, Darmiyati (2009): pendidikan Karakter, Yogyakarta, UNY Press.

------------, Undang-Undang Nomor 20 Tahun 2003 tentang Sistem Pendidikan Nasional (Sisdiknas), Pasal 1 ayat 14.

-----------, Peraturan Menteri Pendidikan Nasional Nomor 58 Tahun 2009 Tentang Standar PAUD, (Kementerian Pendidikan Nasional: Direktorat Pembinaan Anak Usia Dini, Direktorat Jenderal Pembinaan Anak Usia Dini Non Forman dan Informal, 2011.

------------, Peraturan Menteri Agama (PMA) Nomor 90 Tahun 2013 tentang Penyelenggaraan Pendidikan Madrasah. , (2011): "Panduan Kegiatan Belajar Melalui Bermain (Integrasi Pendidikan Nilai-Nilai Kehidupan Beragama)" Kelompok Bermain dan Raudhatul Athfal (RA) Istiqlal, Jakarta, RA Istiqlal. , "Profil dan Kurikulum Pendidikan Anak Usia Dini (PAUD) An-Najah JatinomKlaten" Tahun 2011/2012.

-----------, Profil Raudatul Athfal (RA) Darussalam Tahun 2015.

-----------, Statistik Peserta Didik RA Darussalam tahun ajaran 2014/2015.

Data APK Paud tahun 2014 baru mencapai 72,9 \%, Kemendikbud, http:// www. kemdikbud.go.id/kemdikbud/ berita/2655.

http://www.ra-miftahul-jannah.sch.id/p/ sejarah-berdirinya-taman-kanak_ 8.html. 